\title{
The Communication between Patients and Healthcare Personnel in Psychiatry Hospital
}

\author{
Menekşe Kiliçarslan ${ }^{1 *}$, Rana Özyurt Kaptanoğlu² \\ 1 İstanbul Aydın Üniversitesi, Sağlık Yönetimi, Istanbul- Türkiye (ORCID: 0000-0002-0580-8645) \\ ${ }^{2}$ Medipol Üniversitesi, İktisadi İdari Bilimler Fakültesi, (DSÜ) İşletme Yönetimi Bölümü, İstanbul, Türkiye (ORCID: 0000-0002-0341-4722)
}

(First received 28 December 2019 and in final form 4 March 2019)

(DOI: $10.31590 /$ ejosat.504747)

ATIF/REFERENCE: Kilicarslan, M. \& Kaptanoglu, R. O. (2019). The Communication between Patients and Healthcare Personnel in Psychiatry Hospital. European Journal of Science and Technology, (15), 209-214.

\begin{abstract}
People live together with communication fact in their daily lives. With communication, individuals fulfil their needs in the society. Communication, which has become a popular concept in recent years, is one of the most important issue in the healthcare field. Communication between patients and healthcare personnel is at the forefront in both private sector and public healthcare organizations. While patients are expressing their needs by using tools of communication, healthcare personnel answer their needs with the tools of communication.

With this study, it is aimed to determine the level of communication between patients and healthcare personnel in a public psychiatry hospital; evaluate the problems, which are faced during the communication, in terms of patients and measure the satisfaction levels of patients.

Study is important in terms of the assessment of effects of communication between patient and health care personnel on the satisfaction of patient.

The sampling of this study is consisted of 200 patients in the psychiatry hospital. Academic literature review was made in the study. Questionnaire technique was used for the data collection. After filling in questionnaires with patients face to face, they were computerised by coding and analysed with SPSS 15.0.

With analyses, demographic information of patients, characteristics of healthcare personnel and communication between physician and patient were evaluated.
\end{abstract}

Keywords: Communication, Patient, Health Care Personnel, Health Communication

\section{Psikiyatri Hastanesinde Hastalar ve Sağlık Personeli Arasındaki İletişim}

\section{Öz}

İnsanlar günlük yaşamlarında iletişim gerçeğiyle birlikte yaşıyorlar. İletişim ile bireyler toplumdaki ihtiyaçlarını karşılar. Son yıllarda popüler bir kavram haline gelen iletişim, sağlık alanında en önemli konulardan biridir. Hastalar ve sağlık personeli arasındaki iletişim, hem özel sektörde hem de kamu sağlık kuruluşlarında ön plandadır. Hastalar ihtiyaçlarını iletişim araçlarını kullanarak ifade ederken, sağlık personeli ihtiyaçlarını iletişim araçlarıyla cevaplamaktadır.

\footnotetext{
* Corresponding Author: İstanbul Aydın Universityi, Health Management Department, Istanbul- Turkey (ORCID: 0000-0002-0341-4722), meneksevaro169@gmail.com
} 
Bu çalışma ile bir kamu psikiyatri hastanesinde hastalar ve sağlı personeli arasındaki iletişim seviyesinin belirlenmesi; İletişim sırasında karşılaşılan sorunları hastalar açısından değerlendirebilir ve hasta memnuniyet düzeyini ölçebilir.

Çalışma, hasta ve sağlık personeli arasındaki iletişimin hastanın memnuniyeti üzerindeki etkilerinin değerlendirilmesi açısından önemlidir.

$\mathrm{Bu}$ çalışmanın örneklemini psikiyatri hastanesinde 200 hasta oluşturdu. Çalışmada akademik literatür taraması yapıldı. Veri toplamada anket tekniği kullanılmıştır. Anket formları hastalarla yüz yüze doldurulduktan sonra, kodlama yoluyla bilgisayarlandı ve SPSS 15.0 ile analiz edildi.

Yapılan analizlerle hastaların demografik bilgileri, sağlık çalışanlarının özellikleri ve hekim ile hasta arasındaki iletişim değerlendirildi.

Anahtar Kelimeler: İletişim, Hasta, Sağlık Personeli, Sağlık İletişimi

\section{Introduction}

People live together with communication fact in their daily lives. They continue to live with the tools of communication at home, work, in the street and healthcare organizations. In brief, communication is everywhere. Communication, one of the conditions to be a society, has become a popular concept in recent years and "communication age" term is used to refer the age we are going through. Regional differences have been tried to be solved with these agencies (Bakkal, et. al., 2018:4)

Instead of "iletişim" (communication), which has become popular, "haberleşme" (communications) and "komünikasyon" (derived from France) terms were used. Communication, which comes from Latin "communico", means "exchanging, cooperation".

Communication is a process of knowledge generation, transmission and interpretation (Dökmen, 2003; 19). "Communication is the process of verbal, written or non-verbal transmission of emotions, thoughts, beliefs, attitudes and behaviours in order to affect human behaviours or reach a certain result" (Demirtaş, 2010; 413). Communication is the exchange of message between two units regarding themselves (Cüceloğlu, 2001; 71). There are many definitions for communication in the literature. However, based on these definitions; communication is the transmission of information, emotions and thoughts to the other side with the tools of communication. The voters involved in the political decision-making mechanism are politicians, bureaucrats, groups violate existing legal religious moral and cultural norms in the society by providing private benefits(Bakkal,et. al., 2018:10).

Communication is also important in the health sector in which human relations are dense. The size of communications is determined by the attitudes and behaviours of healthcare personnel and patient (Eriş, 2016;94).

\section{Health Communication}

Although there are scientific and technological developments in the healthcare field, communication is seen as the heart of clinical procedure, including diagnose, treatment and patient (Gordon et. al., 2014; 21). It seems that communication between health personnel and patients influences satisfaction of patients about healthcare services.

Health communication is the practice of concepts and theories of communication about interaction and processes on health between individuals for health improvement (Koçak et. al., 2010;7). We can define health communication as all kinds of interpretation and information transfer between individuals and the healthcare party. In another definition, it is defined as all kinds of human interactions regarding health. Health communication is communication activity that includes every process from transmission of information, thoughts and emotions between patients and health care personnel, involved in health care process to the spread of all kinds of information on health by using mass media.

The concept of health communication, which started to develop within the North American Sciences after 70s, is a brand new issue in Turkey while it has been discussing in Europe for a couple of years. It is difficult to limit this concept, including different disciplines. Uniting social sciences and field of medicine makes difficult to define the concept of health communication (Okay, 2014;10).

\section{Communication Process In Health Care Services}

Physical and psychological characteristics of patients and their relatives, the target group of hospitals, and their expectations are different from psychological characteristics of the target groups of other organizations. Patients and their relatives, who apply to a hospital, are generally under stress with the feelings of uneasiness, anxiety, fear and distress - rather than other people - and, that's why; their psychology or the crisis, which they are going through, can lead them to act in a different way (Tengilimioğlu,2004;181). Hence, communication concept is important when it comes to providing healthcare services.

While providing health care services, personnel communicate directly or indirectly with the patient. Occupational groups that make the closest contact with patients are physicians and nurses among the personnel, providing healthcare services (Adigüzel, 2005; $58)$.

To increase the quality and success of service, provided in the healthcare organizations, personnel should communicate with patients in accordance with their expectations, respect their personal rights and create a safe environment (Atai et.al, 2003; 310).

Communication between Patient-Physician 
Burgoon and et. al., divide the model of interpersonal relationships in three categories as "asymmetric, symmetric and parallel relationships". Asymmetric relationship is the type of relationship that one side plays dominant role and the other side accepts the passive role(Aktürk ,2016:78) In the symmetric relationship, it is believed that both sides have equal rights to determine the relationship. In parallel relationship, every side can control some areas and one can play active role or passive role. In the relationship between patient and physician, patient is completely weak and physician has the authority in every sense (Kaygın, 2012; 74).

The basis of the relationship between patient and physician starts with the demand of patient to understand the medical background of physician. During the treatment process, physicians are expected to fulfil the needs of patients and minimize the fear and stress of them. However, a series of factors determines the structure, content and way of relationship between patient and physician during this process. Within the broadest frame, gender, age, ethnic origin, socio-economic status, the structure of general healthcare system and place are effective factors in the formation of relationship between patient and physician. A direct relationship between patient and physician cannot establish and this causes the problem of miscommunication when all these factors create an asymmetric relationship by engaging (Şengün, 2014;71).

\section{Communication Between Patient-Nurse}

Nursing is one of the professions that directly serves to people by the tools of communication with individuals. The most important instrument of relationship between patient and nurse, who transfers information to the patient and accompanies with $\mathrm{him} / \mathrm{her}$, is communication (Yalçın, 2010;4). In another definition, nursing is defined as the processes of activities, reactions, communication and relationship to meet the basic needs of people from every age and socio-economic status and help them deal with their health problems (Osmenallari, 2014;71).

The relationship between nurse and patient does not realize at once, it is formed by interest and skill; and structured on the confidence of patients in nurse. Confidence takes time. Due to the nature of treatment, the communication between patient and nurse is limited during the short-term treatment in the public or private healthcare organizations but the ability of empathy, one of the basic communication skills, should be used to leave an impression in a short time. However, the relationship between patient and nurse arises inevitably in long-term treatment (Şengün, 2014; 78).

Nurse should pay attention to the verbal and nonverbal communication elements in the relationship between patients. It is stated that body affects $60 \%$, voice affects $30 \%$ and words affects $10 \%$ of communication. In verbal communication, factors like words and intelligibility of them, speaking speed, tone, the use of open and short expressions and timing are important. In non-verbal communication, posture, gests, mimics, gestures, eye contact are effective (Osmenllari, 2014;71).

\section{Communication Between Patient-Heath Care Personnel}

Patients communicate first with allied health personnel when they apply to a hospital in order to get health service. Most of the complaints of people about healthcare organizations is originated at this level. That's why, it is very important that personnel should be highly trained about their duties, communicate good-humouredly with people, who are under stress and patient psychology, and understand them (Osmenllari, 2014;75;).

\section{Material and Method}

\subsection{Research Method And Findings}

In the study, a questionnaire was conducted with 200 patients to determine the nature of communication between patient, getting healthcare service in a public psychiatry hospital, and physician and healthcare personnel. In the light of data, obtained from questionnaires, the level of communication between patient and healthcare personnel was analysed. As a result of the findings, measurements are stated about the problem that can occur because of the miscommunication.

While determining the questions, we benefit from the questionnaire form, in the master's thesis by Edlira Osmenllari on The Impact of Communication to the Satisfaction of the Patient in Health Institutions: Albania Central Military in The Hospital One Implementation. The first part includes demographic information of patient; the second part includes questions about the communication between psychiatric patients and healthcare personnel, apart from physicians.

\subsubsection{Findings And Interpretation}

Table 1. Demographic Information

\begin{tabular}{l|l|r|r}
\hline \multicolumn{2}{l|}{ Variables } & Number of Patient & $\%$ \\
\hline \multirow{2}{*}{ Gender } & Female & 135 & 67,5 \\
\cline { 2 - 4 } & Male & 65 & 32,5 \\
\hline \multirow{2}{*}{ Age } & Under 25 & 42 & 21,0 \\
\cline { 2 - 4 } & Between 26-35 & 41 & 20,5 \\
\hline
\end{tabular}




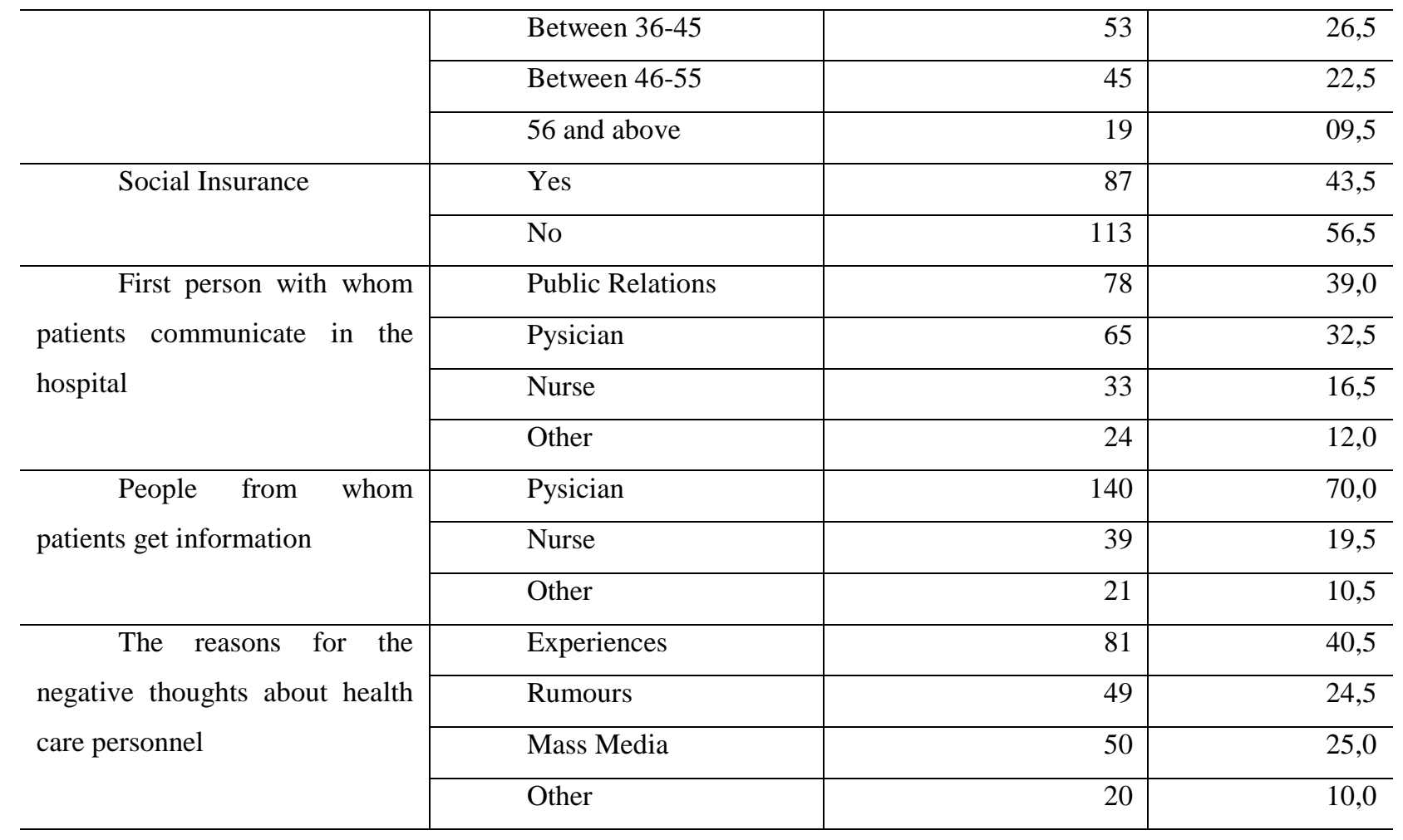

$67,5 \%$ of the participants is female and $32,5 \%$ of them is male. $56,5 \%$ of the participants does not have social insurance, $43,5 \%$ of them has social insurance. When it is anaylzed the age distribution of participants, it can be said participants, between 36-45, are the majority with the rate of $26,5 \%$ and participants, 56 and above, are the minority with the rate of $9,5 \%$. The remaining age ranges are respectively; participants, between $46-55$, with the rate of $22,5 \%$, participants, between $26-35$, with the rate of $20,5 \%$, participants, under 25 , with the rate of $21 \%$.

When participants were asked about the first person with whom patients communicate in the hospital, $39 \%$ of the participants answered as public relations, the most common answer. After public relations, they answered as physician with the rate of 32,5 , nurse with the rate of $16,5 \%$ and other with the rate of $12 \%$. Similarly, participant were asked about people from whom patients get information and answers are respectively; physician with the rate of $70 \%$, nurse with the rate of $19,5 \%$, other with the rate of $10,5 \%$.

Table 2. Demographic Information

\begin{tabular}{|c|c|c|c|c|c|c|c|c|c|c|}
\hline \multirow[t]{2}{*}{$\begin{array}{c}\text { Quesitons About Healthcare } \\
\text { Personnel }\end{array}$} & \multicolumn{2}{|c|}{$\begin{array}{l}\text { Strongly } \\
\text { Disagree }\end{array}$} & \multicolumn{2}{|c|}{ Disagree } & \multicolumn{2}{|c|}{$\begin{array}{l}\text { Neither Agree } \\
\text { Nor Disagree }\end{array}$} & \multicolumn{2}{|c|}{ Agree } & \multicolumn{2}{|c|}{$\begin{array}{c}\text { Strongly } \\
\text { (Agree) }\end{array}$} \\
\hline & $\mathbf{N}$ & $\%$ & $\mathbf{N}$ & $\%$ & $\mathbf{N}$ & $\%$ & $\mathbf{N}$ & $\%$ & $\mathbf{N}$ & $\%$ \\
\hline $\begin{array}{l}\text { I do not have any negative thoughts } \\
\text { about healthcare personnel }\end{array}$ & 6 & 3,0 & 10 & 5,0 & 20 & 10,0 & 102 & $\overline{51,0}$ & 62 & 31,0 \\
\hline I think my expectations were met & 6 & 3,0 & 9 & 4,5 & 65 & 32,5 & 93 & 46,5 & 27 & 13,5 \\
\hline Personnel helped me sufficiently & 3 & 1,5 & 11 & 5,5 & 48 & 24,0 & 105 & 52,5 & 33 & 16,5 \\
\hline $\begin{array}{l}\text { I know that working conditions of } \\
\text { healthcare personnel are difficult. }\end{array}$ & 17 & 8,5 & 26 & 13,0 & 72 & 36,0 & 75 & 37,5 & 10 & 5,0 \\
\hline $\begin{array}{l}\text { I think that patient also partakes in } \\
\text { a possible problem. }\end{array}$ & 30 & 15,0 & 37 & 18,5 & 52 & 26,0 & 47 & 23,5 & 34 & 17,0 \\
\hline $\begin{array}{l}\text { I have enough information about } \\
\text { patient rights. }\end{array}$ & 25 & 12,5 & 9 & 4,5 & 48 & 24,0 & 78 & 39,0 & 40 & 20,0 \\
\hline $\begin{array}{l}\text { I think that personnel treats } \\
\text { everyone equally. }\end{array}$ & 5 & 2,5 & 17 & 8,5 & 81 & 40,5 & 41 & 20,5 & 56 & 28,0 \\
\hline $\begin{array}{l}\text { I think that personnel is patient with } \\
\text { patients. }\end{array}$ & 20 & 10,0 & 24 & 12,0 & 52 & 26,0 & 65 & 32,5 & 39 & 19,5 \\
\hline $\begin{array}{l}\text { I think that personnel acts } \\
\text { authoritatively. }\end{array}$ & 18 & 9,0 & 26 & 13,0 & 49 & 24,5 & 71 & 35,5 & 36 & 18,0 \\
\hline $\begin{array}{l}\text { I think that personnel cares about } \\
\text { patients. }\end{array}$ & 3 & 1,5 & 29 & 14,5 & 50 & 25,0 & 88 & 44,0 & 30 & 15,0 \\
\hline $\begin{array}{l}\text { I think that personnel } \\
\text { communicates with patients } \\
\text { pleasantly. }\end{array}$ & 2 & 1,0 & 11 & 5,5 & 57 & 28,5 & 85 & 42,5 & 45 & 22,5 \\
\hline
\end{tabular}




\begin{tabular}{l|r|r|r|r|r|r|r|r|r|r}
\hline $\begin{array}{l}\text { I think that personnel is good- } \\
\text { humoured. }\end{array}$ & 12 & 6,0 & 32 & 16,0 & 50 & 25,0 & 68 & 34,0 & 38 & 19,0 \\
\hline $\begin{array}{l}\text { I think that the physical appearance } \\
\text { of the patient affects the behaviour } \\
\text { of personnel. }\end{array}$ & 31 & 15,5 & 46 & 23,0 & 43 & 21,5 & 52 & 26,0 & 28 & 14,0 \\
\hline $\begin{array}{l}\text { I think that personnel informs } \\
\text { patient adequately. }\end{array}$ & 5 & 2,5 & 13 & 6,5 & 28 & 14,0 & 79 & 39,5 & 75 & 37,5 \\
\hline $\begin{array}{l}\text { The communication of personnel } \\
\text { with patient is satisfactory. }\end{array}$ & 4 & 2,0 & 7 & 3,5 & 62 & 31,0 & 84 & 42,0 & 43 & 21,5 \\
\hline I recommend this hospital to others. & 13 & 6,5 & 17 & 8,5 & 32 & 16,0 & 79 & 39,5 & 59 & 29,5 \\
\hline
\end{tabular}

When we analyse the table, maximum 102 participants answered as "agree" with the rate of $51 \%$ about if they have positive thoughts about health care personnel. $3 \%$ of the participants answered as "strongly disagree". About meeting the expectations, $46,5 \%$ of the participants gave positive answer, only $3 \%$ of the participants gave negative answer.

It was observed that $52,5 \%$ of the participants answered as "agree" about whether personnel helped them sufficiently. Also, $37,5 \%$ of the participants agreed that working conditions of health care personnel is difficult.

$26 \%$ of the participants answered as "neither agree nor disagree" about the questions, which two parts have fault related to problems but they gave an objective answer by agreeing with the rate of $23,5 \%+17 \%$. It is seen that $12,5 \%+4,5 \%=17 \%$ of the participants does not have enough information about patient rights.

$35,5 \%$ of the participants answered as "agree" about whether personnel acts like authoritarian. It can be seen on the table that $34 \%$ of the participants said that personnel communicates with patients pleasantly, $32,5 \%$ of the participants answered as "agree" about whether personnel is patient with patients, $34 \%$ of the participants answered as "agree" about whether personnel is goodhumoured.

There are close results about whether the physical appearance of patients affects the behaviour of personnel. However, participants answered as "agree" with the rate of $26 \%$ at most.

Participants answered as "agree" with the rate of $39,5 \%$ about whether personnel informs patient adequately and $42 \%$ about whether the communication of personnel with patient is satisfactory. The last question was about whether they recommend this hospital to others and the level of satisfaction related to the hospital. $39,5 \%$ of the participants answered as "agree" to this questions.

\section{Results and Discussion}

\subsection{Conclusion}

As a result of the study, mostly positive answers were given about the general characteristics of personnel in terms of being patient, good-humoured and explanatory. Participants come to agree that personnel should treat everyone equally. However, they are generally pleased with the attitudes and behaviours of personnel in the given hospital, moreover; they gave feedback about recommending it to the others.

One of the main aim of the study is to determine the nature of communication between healthcare personnel and patient, the factors, which affect the nature of communication; and act to improve this communication.

Participants answered as "physician" with the rate of $39 \%$ and "public relations" with the rate of $32,5 \%$ about the first person with whom they communicate and this shows that other people, who communicate with patients, do not work efficiently. However, the first mission of physician is to treat patient so there should be other groups, and units with which patient communicate.

One of the points, which patients emphasize, is waiting-period although there was not any question about this subject. Waitingperiod puts a strain on patients' nerve and causes a nerve interaction before the communication starts. In this regard, it is a satisfactory innovation for patients to give electronic order number.

Individuals should be dealt with as a whole in the healthcare services. To improve communication; workload of the personnel can be reduced, seminars and conferences on communication can be organized, explanatory boards can be arranged for patients, physical conditions of hospitals can be improved and advisory units can be increased. In addition, today's marketing conditions develops in the direction of determining what the expectations of customers are. By conducting a questionnaire to determine the expectations of patients, it is possible to determine possible problems in advance and make improvements about them. 


\section{References}

ADIGÜZEL, Z. (2005), "The nature of Communication between Health Care Personnel-Patient and Factors That Affect This Communication: A case study on Celal Bayar University, Faculty of Medicine Research And Application Hospital, Celal Bayar University, Institute of Social Sciences

ATAÇ, A., AZAL Ö,UÇAR M. et. al.,(2003), Research on the satisfaction of Personnel, who gets health care services from Health Care Organizations under TAF (Turkish Armed Forces) about patient rights and relationship ship between health care personnelpatient on the Intranet,

BAKKAL, M., BAKKAL, S., YILDIRIM H.(2018), Regional Economic Instabilities in Turkey and Ways Of Solution, Social Sciences Studies Journal , Mart, V:4 ,Issue:15,p.799-800

BAKKAL,S.,BAKKAL,M.,KANTAR M.(2018), The Effects Of 1 November 2015 Elections In Turkey On Macro Economy, TURAN-SAM Uluslararası Bilimsel Hakemli Dergisi; ISSN: 1308-8041, e-ISSN: 1309-4033; Y1l: 2018; Cilt: 10/KIŞ, Sayı: $37, \mathrm{P} .229$

CÜCELOĞLU, D.(2001), Yeniden İnsan Insana (Person to Person, Once Again), 26th Edition, Remzi Publishing, İstanbul

DEMIRTAŞ, M. "The Usefulness Of Communication Tools During On The Efficiency And Effectiveness of Organizational Communication and The Sample Of Public Relations Films", Marmara University, İiBF Journal of Faculty of Economics and Administrative Sciences , V.28, I.1, İstanbul, 2010, p.413

DÖKMEN, Ü.,(2003), İletişim Çatışmalar ve Empati (Conflicts of Communication and Emphaty), Sistem Publishing , 22th Edition, İstanbul

ERIŞ, H.(2016) “Hemşirelerin Hastanelerde Kullandıkları Elektronik Tıbbi Kayıtlar Hakkındaki Görüşleri: Şanlıurfa Örneği”, Sağlık Akademisyenleri Dergisi, Health Care Acad J. 2016; 3(3): 93-99, Doi: 10.5455/sad.13-1477551776

GORDON, T and EDWARDS, W.Sterling (2014) "Communication between Patient and Physician" Profil Publishing, $1^{\text {st }}$ Edition, İstanbul

KAYGIN, N. (2012), "Quality, Patient Satisfaction And Patient Nurse Relations İn Health Services”, Master's Thesis, Beykent University, Institute of Social Sciences

KOÇAK, A. and BULDUKLU, Y. "Health Communication: The Viewing Motivations Of Health Programs On Television By Elder People" Selçuk University, Academic Journal of Faculty Of Communication V.6, I:3, Konya, 2010, p.7

OKAY, A. (2014) “Sağlık İletişimi (Healthcare Communication)” Derin Publishing, 2nd Edition, İstanbul

OSMENLLARİ, E. (2014), "The Impact Of Communication To The Satisfaction Of The Patient in Health Institutions: Albania Central Military in The Hospital One Implementation”, Master’s Thesis, Gazi University, Institute of Social Sciences

ŞENGÜN, S. (2014), "Area Health Communication, Communication An Application in The Patients And Health Problems On Bayındır State Hospital Staff”, Master's Thesis, Beykent University, Institute of Social Sciences

TENGiLİMOĞLU, D., KILIÇ, M.,(2004), Public Relations in Hospitals, Hacettepe University- Journal of Faculty of Economics and Administrative Sciences, Aralık,V:2,I:2,p.175-197.

YALÇIN, E.G. (2010), "Patient-Nurse İnteraction in Acute Psychiatric Wards from Nurses' Perspective”, Master's Thesis, İstanbul University, Institute of Social $\quad$ Sciences file:///C:/Users/TEMP/Desktop/İletișim/Kanıta\%20Dayal1\%20Sağl1k\%20Bilișimi.pdf on 10th September 2017:20.00 